\title{
Seasonality of North Atlantic phytoplankton from space: impact of environmental forcing on a changing phenology (1998-2012)
}

\author{
FERNANDO GONZÁLEZ TABOADA and RICARDO ANADÓN \\ Área de Ecología, Dpto. Biología de Organismos y Sistemas, de la Universidad de Oviedo, C/Valentín Andrés Álvarez s/n, E33071 \\ Oviedo, Asturias, Spain
}

\begin{abstract}
Seasonal pulses of phytoplankton drive seasonal cycles of carbon fixation and particle sedimentation, and might condition recruitment success in many exploited species. Taking advantage of long-term series of remotely sensed chlorophyll $a$ (1998-2012), we analysed changes in phytoplankton seasonality in the North Atlantic Ocean. Phytoplankton phenology was analysed based on a probabilistic characterization of bloom incidence. This approach allowed us to detect changes in the prevalence of different seasonal cycles and, at the same time, to estimate bloom timing and magnitude taking into account uncertainty in bloom detection. Deviations between different sensors stressed the importance of a prolonged overlap between successive missions to ensure a correct assessment of phenological changes, as well as the advantage of semi-analytical chlorophyll algorithms over empirical ones to reduce biases. Earlier and more intense blooms were detected in the subpolar Atlantic, while advanced blooms of less magnitude were common in the Subtropical gyre. In the temperate North Atlantic, spring blooms advanced their timing and decreased in magnitude, whereas fall blooms delayed and increased their intensity. At the same time, the prevalence of locations with a single autumn/winter bloom or with a bimodal seasonal cycle increased, in consonance with a poleward expansion of subtropical conditions. Changes in bloom timing and magnitude presented a clear signature of environmental factors, especially wind forcing, although changes on incident photosynthetically active radiation and sea surface temperature were also important depending on latitude. Trends in bloom magnitude matched changes in mean chlorophyll a during the study period, suggesting that seasonal peaks drive long-term trends in chlorophyll $a$ concentration. Our results link changes in North Atlantic climate with recent trends in the phenology of phytoplankton, suggesting an intensification of these impacts in the near future.
\end{abstract}

Keywords: MODIS, North Atlantic Ocean, Ocean Colour, Phytoplankton phenology, Remote sensing, SeaWiFS

Received 29 October 2012 and accepted 30 July 2013

\section{Introduction}

Seasonal pulses of phytoplankton growth set the rhythm of marine ecosystems (Barnes \& Hughes, 1999), and represent an important influx of atmospheric $\mathrm{CO}_{2}$ into the oceans (Falkowski et al., 1998). These events drive seasonal cycles of particle sedimentation (Deuser \& Ross, 1980; Honjo, 1982; Billett et al., 1983) and are tightly linked to the ecology of zooplankton (Longhurst, 2007), including the early stages of many exploited species (Hjort, 1914; Cushing, 1990; Townsend et al., 1994; Durant et al., 2007). The timing and characteristics of seasonal peaks are a major indicator of the functioning of marine pelagic ecosystems (Platt \& Sathyendranath, 2008; Racault et al., 2012). In land, both the phenology of vegetation and migratory species have been altered by recent climate change (Peñuelas \& Filella, 2001;

Correspondence: Fernando González Taboada, tel. +34 98510 4815, fax +34 98510 4777,

e-mail: fgtaboada@gmail.com
Parmesan, 2007; Sletzer \& Post, 2009), while the sea analyses based on long-term field sampling programmes have shown consistent changes both in the phenology and biomass of marine plankton (Reid et al., 1998; Edwards et al., 2001; Edwards \& Richardson, 2004).

The ephemeral nature of changes in phytoplankton and their spatial extent make their characterization difficult by classical sampling techniques. This has been remediated to some extent by the availability of decade long, high-quality remotely sensed monitoring of chlorophyll $a$ concentration (hereafter, chl a) (McClain et al., 2004a; McClain, 2009). Analyses incorporating satellite data have revealed a tight link between climate variability and recent decreases in phytoplankton biomass and primary productivity at the global scale (Gregg \& Conkright, 2002; Antoine et al., 2005; Gregg et al., 2005; Behrenfeld et al., 2006; Martinez et al., 2009; Vantrepotte \& Mélin, 2009), the expansion of low chl $a$ concentration areas in the subtropics (McClain et al., 2004b; Polovina et al., 2008; Irwin \& Oliver, 2009) and a 
decline in mean phytoplankton cell size (Polovina \& Woodworth, 2012). Studies on marine phenology have focused on the main peak of phytoplankton growth in temperate and polar regions, i.e. the spring phytoplankton bloom, and have highlighted the great variability in this event and a trend towards an early occurrence of these blooms in northern latitudes in recent years (Siegel et al., 2002; Platt \& Sathyendranath, 2008; Henson et al., 2009; Kahru et al., 2011; Zhai et al., 2011), as well as the importance of trophic mismatches (Beaugrand et al., 2003; Platt et al., 2003; Koeller et al., 2009; Kristiansen et al., 2011). Secondary pulses during the fall in temperate latitudes and autumn/winter blooms in subtropical and tropical regions have received in general less attention (but see Ueyama \& Monger, 2005; Martinez et al., 2011; Cole et al., 2012; Sapiano et al., 2012).

Here, we combine SeaWiFS and MODIS data to study recent changes in the seasonality of phytoplankton in the North Atlantic Ocean. We develop a methodology which accommodates the different nature of spring and autumn/winter blooms, allowing us to study both events simultaneously. At the same time, the method allows propagating uncertainty in bloom detection to estimates of the change in the extent of areas presenting different types of seasonal cycles, as well as to estimates of the timing and magnitude of seasonal peaks. On the basis of this approach, we examine whether recent ocean colour observations reveal (i) a geographical shift in the incidence of different kind of seasonal cycles; (ii) changes in the timing and magnitude of spring and autumn/winter blooms, and their relationship to trends in chl $a$ concentration; and (iii) the potential ability of different environmental factors to explain recent changes in the phytoplankton seasonality in the North Atlantic.

\section{Materials and methods}

\section{Data sources and data preparation}

A box between $110^{\circ} \mathrm{W} 10^{\circ} \mathrm{S}$ and $50^{\circ} \mathrm{E} 80^{\circ} \mathrm{N}$ was selected to study changes in the seasonality of phytoplankton in the North Atlantic Ocean and its marginal seas. Chlorophyll $a$ is commonly used as an index of phytoplankton biomass and thus of changes in phytoplankton abundance or size. The main advantage of $\operatorname{chl} a$ is that its concentration in the near surface can be readily measured from space (McClain, 2009), but at the cost of ignoring deep chlorophyll maxima. The use of chl $a$ as an index of phytoplankton biomass is further confounded in general by changes in nutrient availability and in the light regime that modulate pigment cell levels (Laws \& Bannister, 1980), problems that might be especially important in subtropical latitudes (see below). Moreover, changes in phytoplankton species composition might alter as well the relationship between chl $a$ concentration and biomass.
Daily time series of remotely sensed chl a concentration [mg m${ }^{-3}$ ] between September 1997 and April 2013 were retrieved from Level 3 (geolocated, corrected and averaged over a regular grid) SeaWiFS (Sept. 1997-Dec. 2007, reprocessing R2010.0) and Aqua MODIS (Jul. 2002-Apr. 2013, reprocessing R2013.0) standard mapped images (SMI) available at the Ocean Color Web (Feldman \& McClain, 2012; Goddard Space Flight Center, NASA; oceancolor.gsfc.nasa.gov). Note that long data gaps due to instrument failures beginning in January 2008 prevented the use of SeaWiFS data available up to December 2010. Original data at a nominal scale of $9 \mathrm{~km}$ were averaged over a $0.25^{\circ}$ grid (cell side ca. $25 \mathrm{~km}$ ). We used chl $a$ concentration maps estimated using the Garver-SiegelMaritorena semi-analytical model (GSM, Garver \& Siegel, 1997; Maritorena et al., 2002). The GSM presents some advantages over other algorithms when data from different missions are combined, given that it is based on a common parameterization independent of the sensor employed to measure ocean colour (Maritorena et al., 2010; note that problems reported in this article related to the drift of the 412 and $443 \mathrm{~nm}$ bands of Aqua MODIS were corrected in the last reprocessing [R2013.0]; see Meister et al., 2012 and oceancolor.gsfc.nasa.gov/WIKI/ OCReproc2013\%282e\%290MA.html). Despite this advantage, deviations between different sensors are still expected as a consequence of differences in their radiometry (Maritorena et al., 2010). To assess the impact of our choice of the GSM algorithm, we repeated all the analyses using chl a estimates retrieved using the sixth version (OCv6, oceancolor.gsfc.nasa.gov/REPROCESSING/R2009/ocv6) of the OC4 (SeaWiFS) and OC3M (Aqua MODIS) empirical band-ratio algorithms (O'Reilly et al., 2000), to check the robustness of our approach to the algorithm employed to estimate chl $a$ concentration (see the Supporting Text in the Supporting Information).

Sea surface temperature (SST) data were used to delimit different seasons and thus to help in the detection and characterization of increases in chl $a$ concentration (a 5 day filter was previously applied to time series to avoid spikes). Data for other environmental variables and indexes were retrieved to study the physical forcing on the timing and magnitude of seasonal peaks during the study period. Climate variables gridded to the same spatial and temporal scale of the chl $a$ observations included SST, incident photosynthetically available radiation (PAR), wind speed and eddy kinetic energy (Table 1).

\section{Characterization of seasonal changes in chlorophyll a concentration}

Seasonal cycles of chl a concentration present a wide variation in the North Atlantic, reflecting changes in physical, chemical and biological conditions from the equator to the poles (e.g., Longhurst, 2007). This includes seasonal regimes characterized by either one or two peaks in chl $a$, which have been typically associated with seasonal changes in stratification (i.e. the spring phytoplankton bloom) or mixing (autumn/winter blooms) (Dutkiewicz et al., 2001). Seasonal increases in chl $a$ concentration near the surface reflect both changes in 
Table 1 Environmental variables employed to assess the potential importance of climate forcing to explain interannual changes in phytoplankton seasonality

\begin{tabular}{|c|c|}
\hline $\begin{array}{l}\text { Variable name } \\
\text { (abbreviation } \\
\text { [units]) }\end{array}$ & Source and processing details \\
\hline $\begin{array}{l}\text { Sea Surface } \\
\text { Temperature } \\
\text { (SST [K]) }\end{array}$ & $\begin{array}{l}\text { NOAA Optimum interpolation } 0.25^{\circ} \text { daily SST } \\
\text { analysis (OISST version 2, Reynolds et al., 2007). } \\
\text { Database produced and maintained by C. Liu } \\
\text { and R. W. Reynolds at NCDC, www.ncdc.noaa. } \\
\text { gov/oa/climate/research/sst/oi-daily- } \\
\text { information.php }\end{array}$ \\
\hline $\begin{array}{l}\text { Integrated } \\
\text { Photosynthetically } \\
\text { Available Radiation } \\
\text { (PAR [Einstein } \\
\mathrm{m}^{-2} \text { day }^{-1} \text { ]) }\end{array}$ & $\begin{array}{l}\text { Daily time series of Level } 3 \text { PAR from } 400 \text { to } \\
700 \mathrm{~nm} \text {, available at the Ocean Color Web } \\
\text { (Feldman \& McClain, 2012; Goddard Space } \\
\text { Flight Center, NASA; oceancolor.gsfc.nasa.gov). }\end{array}$ \\
\hline $\begin{array}{l}\text { Wind stress } \\
\left(\tau\left[\mathrm{N} \mathrm{m}^{-2}\right]\right)\end{array}$ & $\begin{array}{l}\text { Derived from daily wind speed }\left[\mathrm{m} \mathrm{s}^{-1}\right] \text { maps } \\
\text { were integrated from the six-hourly, Level } 3 \\
\text { Cross-Calibrated Multi-Platform Ocean Surface } \\
\text { Wind Velocity product (CCMP, Atlas et al., } \\
\text { 2011; available at PO.DAAC, podaac.jpl.nasa. } \\
\text { gov). The drag coefficient was estimated based } \\
\text { on Yelland \& Taylor, 1996; and Yelland et al., } \\
\text { 1998;. }\end{array}$ \\
\hline $\begin{array}{l}\text { Eddy kinetic energy } \\
\left(\text { EKE }\left[\mathrm{m}^{2} \mathrm{~s}^{-2}\right]\right)\end{array}$ & $\begin{array}{l}\text { Derived from the reference series of daily } \\
\text { geostrophic velocity anomalies produced by } \\
\text { Ssalto/Duacs and distributed by Aviso (www. } \\
\text { aviso.oceanobs.com), with support from CNES } \\
\text { (Centre National d'Etudes Spatiales). The } \\
\text { reference series is obtained by merging data } \\
\text { from various missions (Topex/Poseidon, } \\
\text { Jason-1, European Remote Sensing satellites } \\
\text { [ERS } 1 \text { and 2], and Envisat) using the methods } \\
\text { developed by Le Traon et al. (1998). }\end{array}$ \\
\hline
\end{tabular}

Comments

SST not only accelerates the rate of physiological and ecological processes (of phytoplankton and of grazers, Townsend et al., 1994) but it is also a tracer of vertical mixing and of the advection of waters with different properties. Warmer (cooler) waters might be related to increased (decreased) stratification and light exposure and reduced (increased) nutrient availability.

Together with vertical attenuation and mixing depth, incident PAR determines the subsurface light field (e.g., Platt et al., 1991). In this way, a lower PAR might alter chl $a$ concentration by limiting phytoplankton growth rates or by increasing pigment cell levels, and vice versa.

Wind stress is a proxy of wind surface mixing and turbulence, so increased wind stress is related to an increased mixed layer ventilation and nutrient renewal, as well as deeper phytoplankton entrainment, and, in principle, higher dilution and lower encounter rates with grazers (Irigoien $e t$ al., 2005; Behrenfeld, 2010). Nevertheless, air-sea heat fluxes and vertical convection are also important drivers of mixed layer depth at high latitudes.

Eddy kinetic energy is a proxy of variability in ocean currents and mesoscale features which might promote an early stratification and enhance bloom development (Karrasch et al., 1996).

phytoplankton abundance and in the amount of $\operatorname{chl} a$ per cell. Cell concentration might change due to population growth, horizontal advection and dispersion, or as a consequence of changes in vertical distribution (Behrenfeld, 2010). Pigment cell levels vary depending on nutrient availability and on the light field (Laws \& Bannister, 1980). The photoacclimation response is especially important following autumn mixing in subtropical latitudes, when the recirculation of phytoplankters in a deeper mixed layer decreases light exposure and results in an increase in chl $a$ concentration in the water column (Letelier et al., 1993; DuRand et al., 2001; Behrenfeld et al., 2005; Siegel et al., 2005; Westberry et al., 2008; Vantrepotte et al., 2011).

Episodic changes in surface chl $a$ concentration due to other processes alter these seasonal cycles, reflecting for instance the influence of mesoscale features, coastal upwelling and land inputs, to name a few of them. Satellite data allow the identification of all these events, with the main constraint arising from limited data availability during cloudy conditions. Here we adopted a rather practical approach for the identification and characterization of seasonal peaks, trying to avoid the influence of high frequency events. Seasonal extremes in SST were used to delimit each season and to identify candidate periods for seasonal peaks of increase in chl $a$ concentration. We considered a period centred on each calendar year but covering the time period between previous and next year SST maxima (see Jönsson \& Eklundh, 2002). The chl $a$ time series for this period was then smoothed by fitting a generalized linear model assuming Gamma distributed errors using the canonical, inverse link function:

$$
\begin{aligned}
p\left(\operatorname{chl}_{t} \mid \widehat{\operatorname{chl}}_{t}\right) & \sim \operatorname{Gamma}_{(u, v)} \\
\left(\widehat{\operatorname{chl}}_{t}\right)^{-1} & \sim \operatorname{Normal}\left(\beta X, \sigma_{\epsilon}\right)
\end{aligned}
$$

The estimation of the shape and rate parameters of the Gamma distribution ( $u$ and $v$ ) is surpassed in this way by linking the expected $\operatorname{chl} a$ values to the linear predictor $\left(\right.$ et $\left.a_{t}=\beta X\right)$. The linear predictor included an intercept, a linear trend on time and sine and cosine waves to represent the seasonal cycle 
by annual and semi-annual harmonics ( $\omega=1 / 365$; see Vargas

1 et al., 2008; Sapiano et al., 2012), yielding the equation:

$$
\begin{aligned}
\eta_{t}= & \beta_{0}+\beta_{1} t+\beta_{2} \sin (2 \pi \omega t)+\beta_{3} \cos (2 \pi \omega t)+\beta_{4} \sin (4 \pi \omega t) \\
& +\beta_{5} \cos (4 \pi \omega t)+\beta t \sin (2 \pi \omega t)+\beta_{7} t \cos (2 \pi \omega t)
\end{aligned}
$$

Note that the model allowed also a linear trend in the amplitude of the annual harmonics. This model specification was redundant for some of the series, so we determined an optimal structure based on model ranks determined using the Akaike Information Criterion (AIC, Burnham \& Anderson, 2003), a relative measurement of goodness of fit that includes a penalty term to weight down model complexity and avoid over fitting. The model was fitted under a Bayesian framework, employing the modified Expectation-Maximization algorithm developed by Gelman et al. (2008) and implemented in the $R$ package arm (Gelman et al., 2009; see also Gelman \& Hill, 2007). We assumed standard, weakly informative priors for each $j$ parameter in Eqn (2), i.e.:

$$
\begin{aligned}
& \beta_{j} \sim \operatorname{Cauchy}(\mu, v) \\
& \mu=0 \text { and } \begin{cases}v=10, & j=0 \\
v=\frac{2.5}{2 s d\left(x_{j}\right)}, & j>0\end{cases}
\end{aligned}
$$

where the location parameter $\mu$ centres our prior belief about the mean of posterior parameter values in zero and the scale parameter was tuned depending on the standard deviation of each covariate $x_{j}$ (a larger variation in $x_{j}$ puts more a priori weight in small values of $\beta_{j}$ ).

Posterior parameter distributions were then used to generate an envelope of model realizations (1000) that was employed to propagate model uncertainty to a set of bloom metrics (timing and magnitude) used to characterize the seasonal cycle. Local extremes in chl $a$ delimited periods of accumulation that were considered as candidate blooms if they reached a level above the 60th percentile of a Gamma distribution fitted to chl a observations between consecutive SST extremes (i.e. a minimum and a maximum or vice versa). The choice of this threshold was arbitrary but helped us to reject small amplitude waves. Candidate blooms were then classified either as spring or autumn/winter blooms based on the relative timing of bloom metrics with respect to SST extremes. We considered that a candidate bloom corresponded to a spring bloom if its timing and peak occurred after the seasonal SST minimum but before the SST maximum. Similarly, the timing of autumn/winter blooms must occur between the seasonal SST maximum and the next minimum (avoiding thus possible confusions with next year's spring blooms), even if the timing of the peak occurred after the SST minimum. For a given model realization, only the first candidate bloom meeting the criteria above was retained, although in some cases all the candidates were rejected.

Determining the occurrence of a bloom in this way does not presuppose the development of a bloom every year and compensates to some extent the lack of data during cloudy periods (Gregg \& Casey, 2007; Cole et al., 2012). It is important to note that we defined the timing of the bloom as the day when the net rate of increase in chl $a$ concentration attained a maximum. The definition is similar to other approaches based on a predefined threshold level, although our intention was not to determine the date of bloom initiation. Our definition also differs from the timing of bloom onset, defined by Sverdrup (1953) as the date when the net rate of phytoplankton increase becomes positive. With our definition, we tried to prevent potential measurement errors in the net rate of increase associated with the small changes in chl $a$ concentration at the onset of the bloom, and due to the lack of data during cloudy periods in northern latitudes. On the other hand, bloom magnitude was defined as the peak chl $a$ concentration attained during the bloom. We also estimated mean chl $a$ concentration during the entire bloom (i.e. between consecutive chl $a$ minima), but only to complement analyses of changes in bloom timing and magnitude. A set of examples have been included in Fig. 1 and a diagram summarizing bloom determination is included in the Supplementary Information (Fig. S6).

\section{Analyses of changes in the seasonality of chl a concentration}

The characterization of seasonal chl $a$ time series resulted in four different possibilities attending to the presence or absence of different peaks. We distinguished mean seasonal cycles presenting (i) a single spring; or (ii) a single autumn/winter bloom; (iii) a spring bloom followed by an autumn/winter one (i.e. a bimodal seasonal cycle); and (iv) mean seasonal cycles in which neither of the blooms were detected. Each of the 1000 posterior model realizations was assigned to any of these categories, resulting in a raw estimate of the probability

Fig. 1 Different types of seasonal cycles of surface chlorophyll $a$ concentration in the North Atlantic. Rows a-d correspond to the four different types of seasonal cycles distinguished. The plots on the left side of each row illustrate the approach employed to characterize seasonal peaks (see also Fig. S6), while the maps on the right present the corresponding probability of occurrence of each type of seasonal cycle in the entire North Atlantic. In the left panels, posterior simulations (blue lines) from a model fitted to remotely sensed observations of chlorophyll $a$ concentration ( $\operatorname{chl} a$, green dots) were used to assess the probability of detecting different peaks in phytoplankton biomass and their timing (histograms). A peak qualified as a bloom after surpassing a threshold chl $a$ concentration (dark grey shading). Identified peaks were classified either as spring or autumn/winter blooms based on the timing of sea surface temperature extremes (SST, orange line), which determined spring or fall candidate periods (grey shaded areas). The series were extracted from the following pixel locations: (a) $12.6^{\circ} \mathrm{W} 55.1^{\circ} \mathrm{N}$, (b) $9.6^{\circ} \mathrm{W} 47.6^{\circ} \mathrm{N}$, (c) $55.1^{\circ} \mathrm{W} 30.1^{\circ} \mathrm{N}$, and (d) $32.6^{\circ} \mathrm{W} 0.6^{\circ} \mathrm{S}$. Probability maps were derived from 15 consecutive seasonal cycles (from 1998-1999 to 2012-2013; data for Aqua MODIS and SeaWiFS were averaged for overlapping seasons), and were based on 1000 posterior simulations of model Eqn 2 fitted to data available during each season. The contour line encloses areas with a probability of detection greater than 0.5. Fig. S8 in the Supporting Information presents maps distinguishing regions with no data and regions where, despite data being available, no peak was detected (e.g., the case illustrated in d). 
(a)

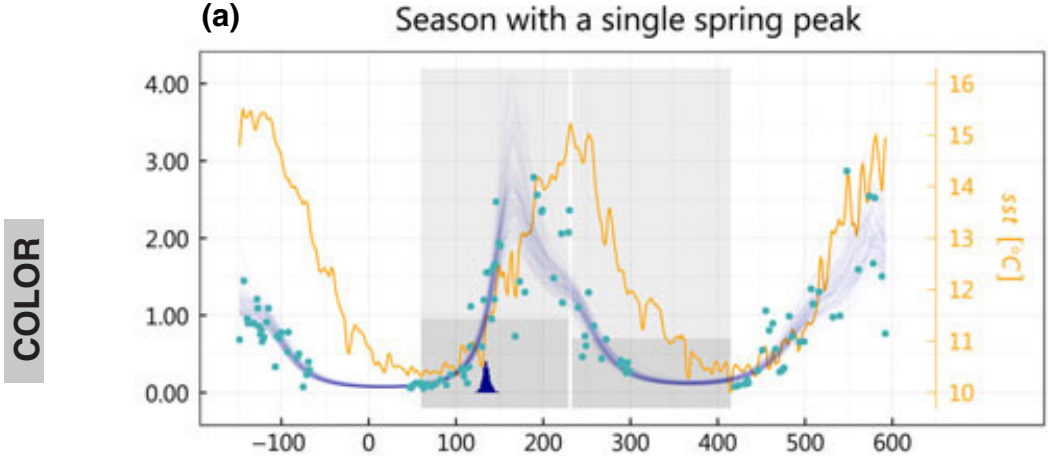

(b)

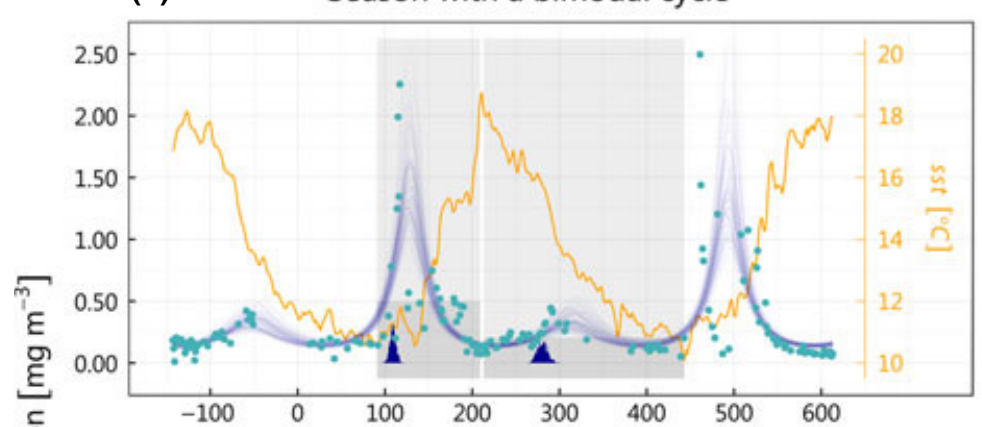

(c) Season with a single autumn/winter peak

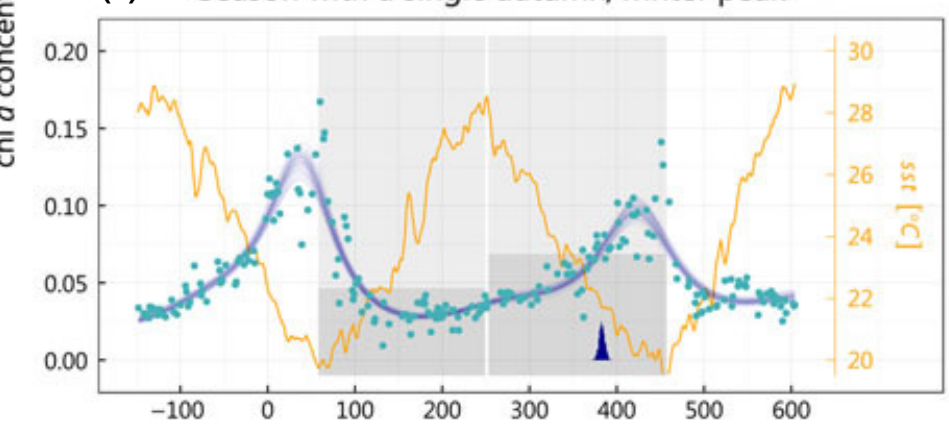

(d)

Undetected seasonal peak

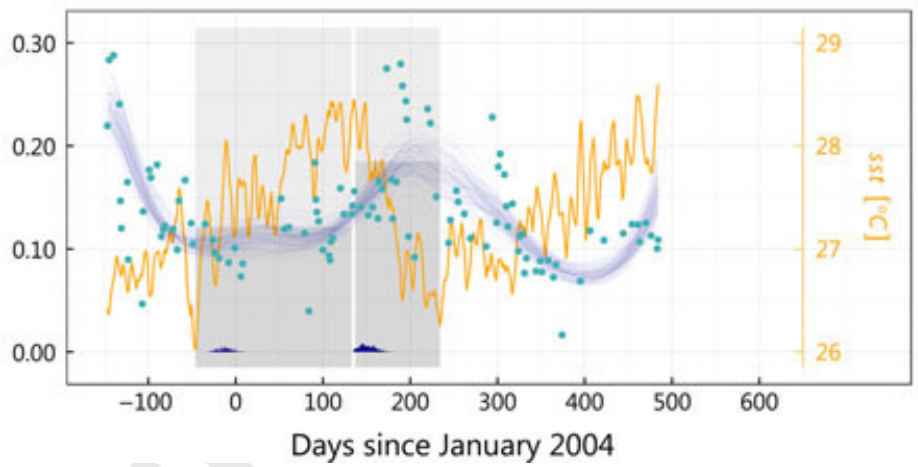

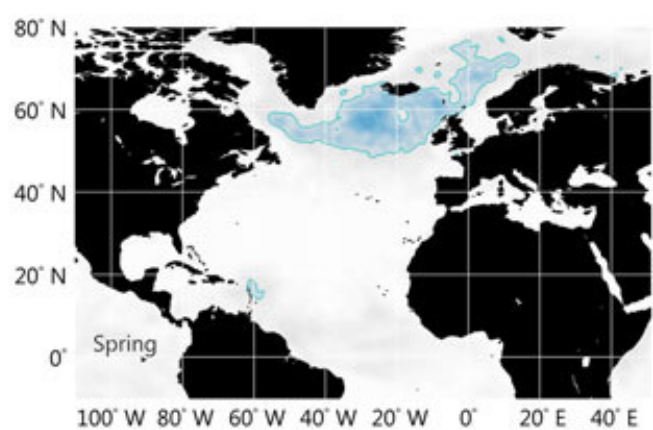
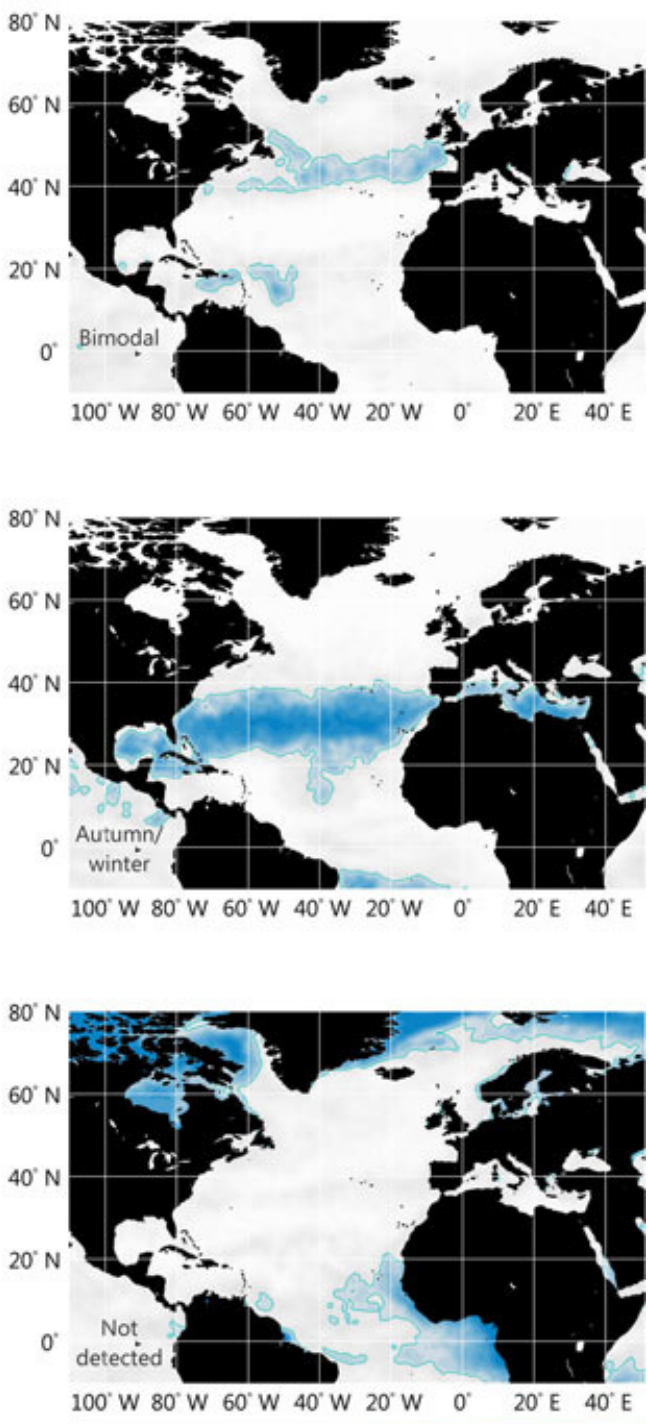

of each kind of seasonal cycle occurring at each pixel location. These probabilities were then integrated over regions defined by grouping biogeochemical provinces delimited by Longhurst (2007) to obtain a weighted estimate of the total areal extent corresponding to each kind of seasonal cycle.
Longhurst's (2007) regions were further subset to avoid marginal seas and to account for differences in the detectability of different seasonal cycles (see Fig. S7). Trends in the prevalence of each type of seasonal cycle were analysed based on a Dirichlet regression model that included a second-order trend in 
time (see Table S2 in the Supporting Information). This kind of model has an error structure ideally suited to analyse compositional data (proportions adding up to unity) in the presence of covariates (Campbell \& Mosimann, 1987; Hijazi \&

2 Jernigan, 2009), and was fitted using an adaptive Metropolis algorithm (Roberts \& Rosenthal, 2009).

Simulations of the model fitted to chl $a$ time series were also employed to obtain an augmented sample of the timing (defined as the day of maximum net increase in chl $a$ ) and magnitude (defined as the peak chl $a$ concentration during a bloom) of blooms occurring at each pixel location. Median timings and magnitudes were estimated at the pixel level, but detection probabilities were retained and employed to weight the reliability of different observations, propagating in this way uncertainty in bloom detection to estimates based on bloom statistics. Interannual changes in bloom metrics were analysed using a model including a fixed effects factor to account for biases between different sensors and a linear trend in time. We assumed normally distributed errors for the residuals of this model, which we considered a reasonable assumption for both bloom timing and bloom magnitude, although in the latter case only after log transformation. Temporal trends in bloom metrics were later compared to trends in mean chl $a$ during the entire year, estimated after fitting Eqn. (2) to the complete daily chl $a$ series using a log link function to ease interpretation. This model thus included a linear trend, a term to account for sensor bias and terms to account for a seasonal cycle potentially changing its amplitude between years.

Estimates of bloom timing and magnitude were also compared to a set of environmental factors to assess the potential importance of climate forcing to explain interannual changes in phytoplankton seasonality. Time series of linearly detrended anomalies of (i) sea surface temperature; (ii) incident photosynthetically active radiation; (iii) wind stress; and (iv) eddy kinetic energy, were standardized to mean zero and standard deviation one. All these variables modulate phytoplankton dynamics and might alter bloom timing and magnitude (Table 1). Detrended anomalies were preferred to represent short-term effects on bloom metrics and to prevent problems of collinearity in models including more than one covariate. Detrending did not affect the patterns of association found with original data in models with a single covariate. The models fitted to time series of bloom metrics assumed normally distributed errors (after log transformation in the case of bloom magnitude) and included again a linear trend and a term to account for sensor bias. Models included all the covariates, although only wind stress or one of its components was included to avoid problems of collinearity (best model structure based on AIC). The fraction of deviance explained by each environmental factor was determined by fitting models excluding sequentially each covariate.

A $0.5^{\circ}$ spatial moving window was employed to augment areal coverage and to reduce spatial noise in all the estimates. The overlap between SeaWiFS and Aqua MODIS during four entire seasons (from 2003-04 to 2006-07 inclusive) allowed us to assess potential biases derived from using data coming from different sensors and satellites, as further detailed in the Supporting Information (see Supporting Text, Table S1 and
Figs. S1-S5). All calculations involving different pixel locations accounted for changes in cell area with latitude using the reference ellipsoid WGS84.

\section{Results \\ Incidence of different types of seasonality}

The cumulated probability of different types of seasonal cycle presented a clear latitudinal pattern with a single spring bloom in the subpolar Atlantic, a single autumn/winter bloom in subtropical latitudes, and a bimodal cycle in temperate latitudes (Fig. 1). There was a clear transition among each pair of regions, with a relatively sharp gradient in detection probabilities (decaying shade intensity outside green contours in Fig. 1). No single type of seasonal cycle dominated in transitional regions, although recurrent blooms were detected when seasons with single and double peaks were pooled together to estimate the probability of occurrence of spring and autumn/winter blooms (indeed they qualified for the estimation of trends in blooms statistics, Fig. 3). This explains for instance the failure to highlight spring blooms in the north-western Mediterranean (Bosc et al., 2004), that were obscured due to the detection of bimodal cycles in some years. Our approach failed to detect a marked seasonal cycle in pixel locations north of $\sim 70^{\circ} \mathrm{N}$ due to data scarcity (see Figs. S2 and S8 in the Supporting Information), and in most of the tropical and equatorial Atlantic, due to multimodal and highly irregular small amplitude seasonal oscillations (Longhurst, 2007). The western tropical Atlantic, near the Antilles, presented an exception to this general pattern. Bimodal and even spring seasonal cycles were common in this region where seasonal peaks are driven by enhanced biological $\mathrm{N}_{2}$ fixation (Coles et al., 2004; Subramaniam et al., 2008).

The prevalence of different types of seasonal cycles changed between seasons (Fig. 2; see also Table S2). The Dirichlet regression results in nonlinear trends in prevalence, so model based estimates for the first and last years will be used to illustrate changes during the study period (1998-2012). In the polar and subpolar North Atlantic (Fig. 2a-d), the prevalence of seasons with a single spring bloom was coupled to changes in the frequency of pixel locations where no bloom was detected (Kendall's $\tau=-0.75$ [-0.59, -0.90$]$; modelbased estimates of the median and $90 \%$ posterior density interval). The prevalence of spring peaks presented also a decrease (e.g., from an estimated fraction of 0.44 $[0.43,0.45]$ in $1998-1999$ to 0.33 [0.30, 0.37] in 20122013 , equivalent to a change in extent of $5.14[3.28,6.91]$ 

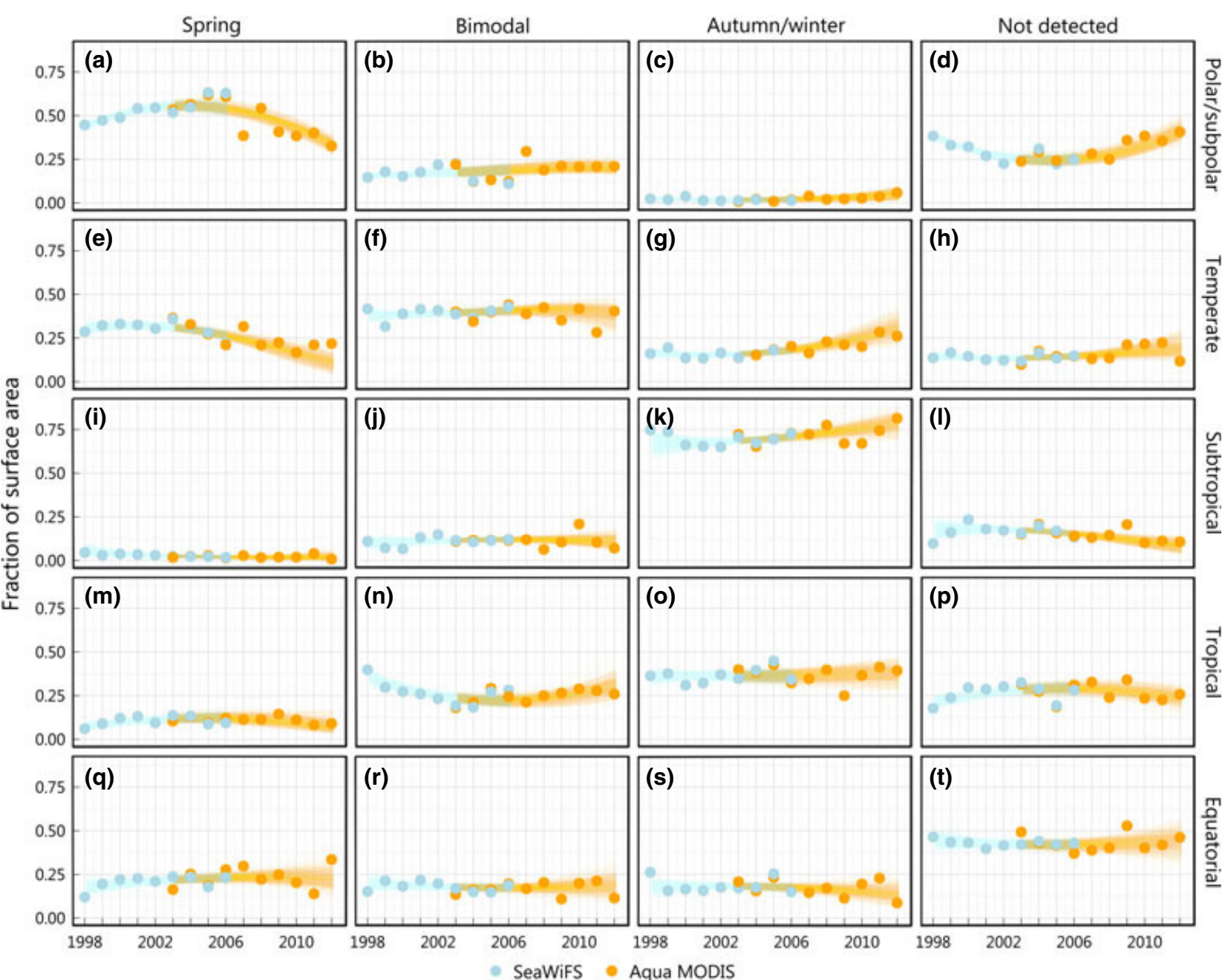

Fig. 2 Prevalence of different types of seasonal cycle in the main biogeochemical regions of the North Atlantic. Each panel presents the incidence of each type of seasonal cycle after correcting for differences in detectability between sensors. Estimates were derived from a weighted integral considering the probabilities for each kind of seasonal cycle (e.g., Fig. 1). Lines correspond to posterior simulations $(n=400)$ from a Dirichlet regression model accounting for differences between sensors and including a second degree polynomial trend to account for nonlinear time trends (Table S2). Alpha blending was employed to represent model uncertainty, with $\alpha=1 / 80$ (i.e. the overlap of 80 lines correspond to full opacity). The regions group biogeochemical provinces defined by (Longhurst, 2007) (see Fig. S7 in the Supporting Information). See Fig. S9 in the Supporting Information for the same figure based on chl $a$ estimates retrieved using the OCv6 band-ratio algorithm.

$\times 10^{5} \mathrm{~km}^{2}$ ), that was compensated in part by a weak increase in bimodal cycles $\left(2.14[0.85,3.85] \times 10^{5} \mathrm{~km}^{2}\right)$.

In temperate regions (Fig. $2 \mathrm{e}-\mathrm{h}$ ), there was a clear decline in the prevalence of locations with a single spring bloom (fraction of area reduced from 0.31 $[0.28,0.34]$ to $0.11[0.06,0.16]$, equivalent to a reduction in extent of $13.2[9.8,16.0] \times 10^{5} \mathrm{~km}^{2}$ ). Although this trend was again negatively related to changes in detectability (e.g., $2.5[-0.0,6.1] \times 10^{5} \mathrm{~km}^{2} ; \tau=-0.81$ $[-0.36,-1.00])$, it was compensated mainly by an increase in the extent of locations with a single autumn/winter bloom $\left(7.68[3.89,12.28] \times 10^{5} \mathrm{~km}^{2}\right.$, $\tau=-0.98[-0.79,-1.00])$ and, to a lesser extent, by an increase in bimodal cycles $\left(1.25[-3.07,4.78] \times 10^{5} \mathrm{~km}^{2}\right.$, $\tau=-0.50[0.41,-0.93]$ ). In the subtropics (Fig. 2i-1), posterior estimates indicated a slight increase in the dominance of seasonal cycles with a single autumn/ winter cycle (from a fraction of $0.68[0.61,0.73]$ to 0.78 $[0.71,0.84])$, mainly at the expense of a reduced incidence of areas where no peak was detected $(\tau=-0.93$ $[-0.66,-1.00])$. No clear temporal trends were detected in tropical and equatorial regions (Fig. $2 \mathrm{~m}-\mathrm{t}$ ), where the prevalence of different seasonal cycles remained almost constant except for some high frequency excursions away from mean prevalence levels coinciding with El Niño events (e.g., 2005-06). 
Timing and magnitude of seasonal peaks

Mean levels and time trends in the timing (defined as the day when the net rate of increase in chl $a$ concentration was maximized during the phase of accumulation in modelled chl $a$ series) and the magnitude of seasonal peaks (i.e. the peak chl a concentration attained) presented a marked spatial structure during the study period (Fig. 3a,d,g,j; see also Fig. S10 and especially Fig. S13 in the Supporting Information for uncertainty associated with these estimates). The comparison of bloom statistics based on data retrieved by different sensors resulted in differences structured in space that were especially important in the case of bloom magni-

\section{Spring bloom}

(a)



(d)

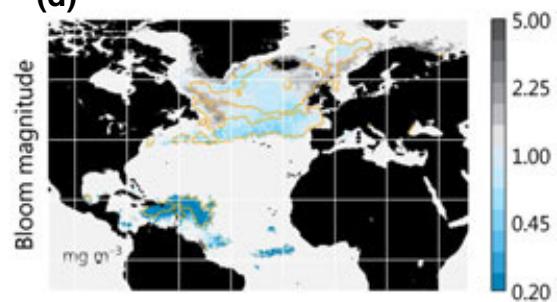

Autumn/winter bloom

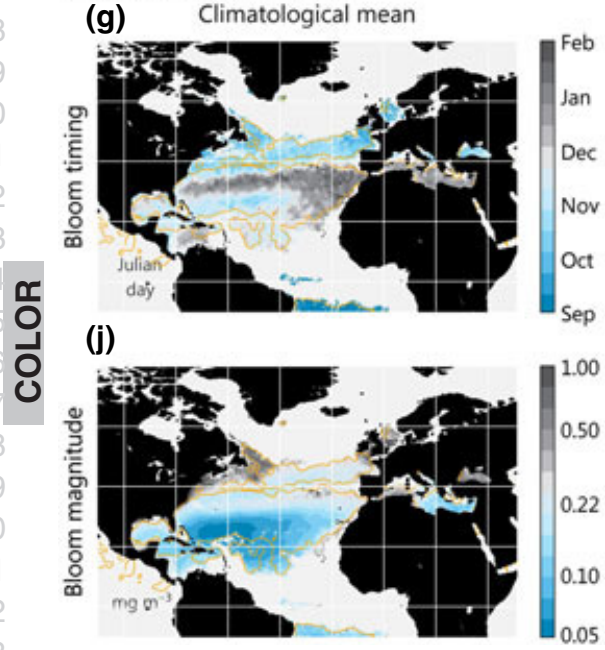



(e)

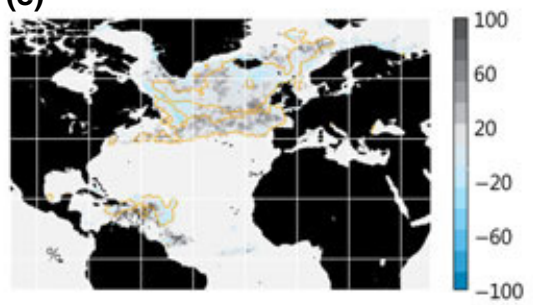

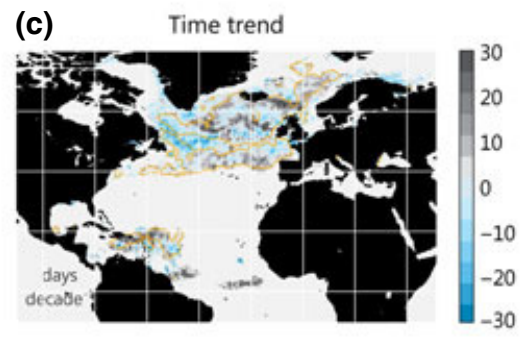

(f)



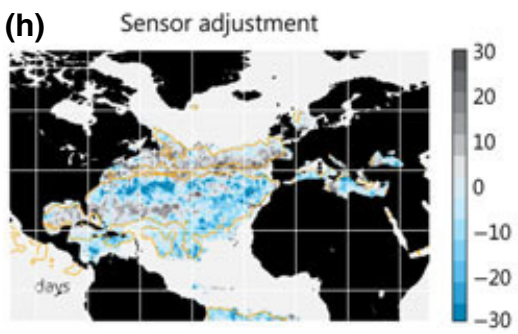

(k)





(I)

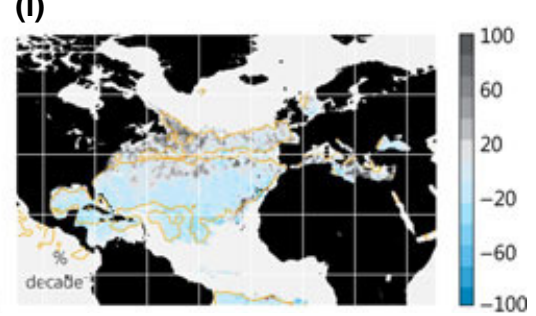

Fig. 3 Timing and magnitude of spring (upper panels) and autumn/winter blooms (lower panels). Maps in each column correspond to the posterior mean date (Julian day) and chl $a$ concentration $\left(\mathrm{mg} \mathrm{m}^{-3}\right)$, the differences between sensors (in days and as a percentage respectively) and the time trends (days or percentage per decade) during 1998-2012 (units are also indicated in the bottom left corner of each map). A model including a linear trend in time was fitted to estimates of bloom statistics. The model included also a fixed effect factor to account for biases in mean bloom metrics between different sensors. Bloom statistics estimated from SeaWiFS data were taken as baseline. The timing (defined as the day when the net rate of increase in chl $a$ concentration attained a maximum during each wave of increase) and the magnitude (defined as the peak chl $a$ concentration attained during a bloom) of spring and autumn/winter blooms was determined for each season and pixel location from posterior simulations of the smoothing model fitted to chl $a$ observations (Eqn 2). Only locations where the cumulated probability of detecting either type of bloom was greater than 0.5 were considered. Estimates corresponding to single-peaked and bimodal seasonalities were pooled together. Orange contours delimit regions where the probability of each type of seasonal cycle is greater than 0.5 (see Fig. 1). Figs. S13 and S14 in the Supporting Information present the uncertainty associated with all these estimates and results based on chl $a$ estimates retrieved using the OCv6 band-ratio algorithm. 
tude (Fig. 3e,k). Spring peaks were detected early in April in the temperate North Atlantic and up to June in the Subpolar gyre (Fig. 3a), although there were some noticeable exceptions, especially in coastal regions. The mean magnitude of spring peaks covered almost two orders of magnitude $\left(0.2-14.4 \mathrm{mg} \mathrm{m}^{-3}\right.$, Fig. 3d) and increased with latitude, although it was mainly influenced by the proximity to land. In the western subtropical Atlantic $\left(10^{\circ}-23.5^{\circ} \mathrm{N}\right)$, low magnitude spring peaks $\left(0.13[0.06,0.65] \mathrm{mg} \mathrm{m}^{-3}\right)$ occurred in late June, except in the region influenced by the Amazon river outflow (median peaks of up to $9.4 \mathrm{mg} \mathrm{m}^{-3}$, but note that chl $a$ concentration retrievals are less reliable in case 2 waters). The timing of autumn/winter peaks presented a more complicated pattern (Fig. 3g). Small amplitude seasonal peaks $\left(0.13[0.06,0.31] \mathrm{mg} \mathrm{m}^{-3}\right.$, Fig. $\left.3 \mathrm{j}\right)$ were detected in late November and December in the southwestern side of the Subtropical gyre, and occurred up to early February towards the north and in the eastern side. The autumn/winter bloom of bimodal seasonal cycles of temperate regions was more intense $(0.26$ $\left.[0.19,0.90] \mathrm{mg} \mathrm{m}^{-3}\right)$. The timing of bimodal autumn/ winter blooms occurred later towards the south; as early as September in regions like the North Sea and up to early November near the Subtropical gyre.

The timing and the magnitude of either spring or autumn/winter blooms presented in general a positive temporal association at the pixel level, except in the case of spring blooms in some locations in the western Subpolar gyre and in polar latitudes (Fig. 4, see also Fig. S11). On a large scale, this relationship resulted in a slight predominance of regions with either delayed and more intense blooms or advancing blooms declining in magnitude (29.0 and $30.1 \%$, respectively, i.e. $59.0 \%$ of the area presented trends of the same sign, Fig. 4). Nevertheless, trends in timing were more heterogeneous in space than trends in bloom magnitude. Trends towards delayed blooms predominated at the basin scale (58.7\%; similar figures for either kind of bloom). Declining bloom magnitudes were more frequent in the case of autumn/winter blooms (62.3\%), and to lesser extent, in the case of spring blooms (54.1\%). The magnitude of spring blooms increased in coastal regions and in the northern North Atlantic, while the magnitude of autumn/winter blooms increased mainly in regions presenting a bimodal cycle.
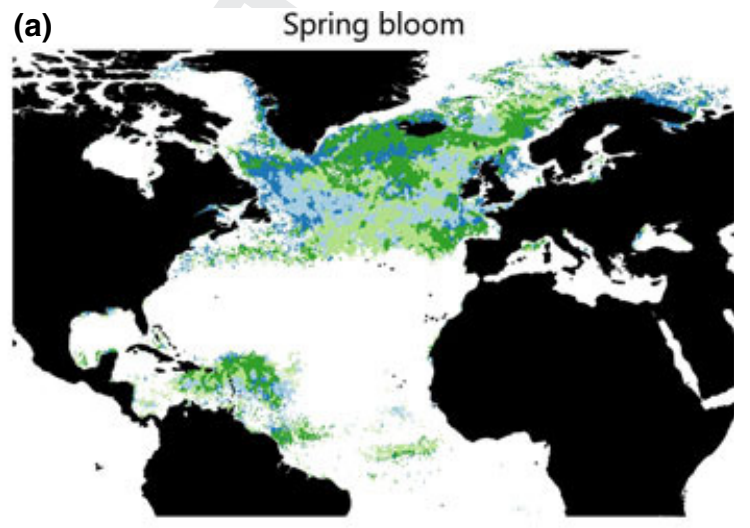

(b)

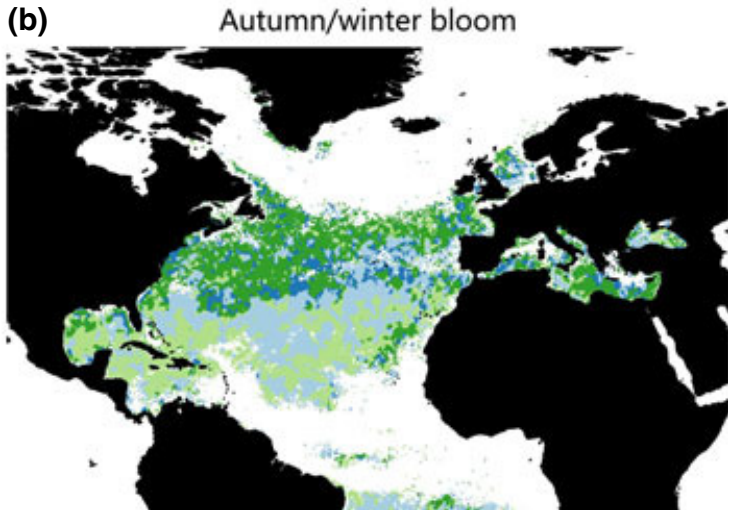

Fig. 4 Categorical maps showing the association between the sign of time trends in the timing and in the magnitude of spring and autumn/winter blooms in the North Atlantic during 1998-2012. Each colour depicts the four combinations between blooms with an advancing or delaying timing and an increasing or decreasing magnitude. 
In general, delays and advances in the timing of spring and autumn/winter blooms were of the same magnitude, although changes in the mean magnitude of blooms of either sign were more important in the case of spring blooms (Fig. 3, see also Figs. S10 and S15). Advanced and less intense spring blooms were common in polar regions (north of $65^{\circ} \mathrm{N}$ ) and in both sides of the Atlantic between $45^{\circ} \mathrm{N}$ and $60^{\circ} \mathrm{N}$. In contrast, trends towards delayed and more intense blooms were common in the Faroe-Iceland ridge, in the Irminger Sea and, in general, in areas north of $55^{\circ} \mathrm{N}$ in the central North Atlantic (e.g., 65.7\% of the locations within the box $40^{\circ} \mathrm{W} 55^{\circ} \mathrm{N}$ and $20^{\circ} \mathrm{W} 65^{\circ} \mathrm{N}$ ). Delayed spring and autumn/winter blooms also predominated along the southern limit of regions presenting bimodal cycles in temperate latitudes. Interestingly, trends towards a longer interval between the timing of both blooms predominated in temperate regions presenting bimodal cycles $(71.4 \%)$. At the same time, the magnitude of spring blooms declined whereas autumn/winter blooms were more pronounced. This last result contrasted with the conspicuous predominance of trends towards less intense blooms in regions with a single autumn/winter bloom (67.1\%). Advanced autumn/winter blooms predominated in the interior of the Subtropical gyre, although delayed blooms were common along its southern boundary and in marginal seas like the Mediterranean Sea and the Caribbean Sea.

Mean chl $a$ concentration decreased in most of the North Atlantic during the study period (60.5\%). This pattern was determined mainly by the higher prevalence of negative trends in the tropical and subtropical North Atlantic (Fig. S17). Changes in mean chl a concentration varied between regions depending on the type of mean seasonal cycle. Areas with a single autumn/ winter bloom presented in general a decrease in mean chl $a$ (78.0\%), while increasing and decreasing trends were equally important in areas with bimodal seasonal cycles $(46.5 \%)$. In the case of areas with a single spring bloom, trends towards increased chl $a$ predominated $(81.2 \%)$. This contrasting response is indicative of the tight link between changes in seasonal peaks and decadal changes in mean chl $a$ concentration. We further examined the correspondence between changes in bloom timing and magnitude and changes in mean chl $a$ concentration at the pixel level (Fig. S18). Changes in the magnitude of seasonal peaks were of the same signs as changes in mean chl $a$ (i.e. coherent changes in 59.2 and $77.4 \%$ of the areas presenting spring and autumn/ winter blooms respectively), something relevant considering the lower coherence with trends in mean chl $a$ during the entire bloom (53.4 and $64.0 \%$, i.e. between consecutive chl $a$ minima). On the other hand, no clear association was detected between the sign of trends in bloom timing and in mean chl $a$ concentration (i.e. coherent sign of trends in just 49.3 and $53.4 \%$ for spring and autumn/winter blooms respectively).

Impact of environmental factors on the timing and magnitude of blooms

The influence of environmental factors on spring and autumn/winter blooms presented a similar spatial pattern for bloom timing and magnitude (Figs. 4, S19 and S20). Each environmental variable presented marked and spatially coherent trends that in some cases varied between the cold and the warm seasons (Fig. S21). These trends also varied spatially, although they were indicative of a basin scale trend towards warmer surface waters and increased cloudiness (i.e. reduced PAR). Changes in wind stress were more complex, with a decline in most of the basin associated with the negative trend in the North Atlantic Oscillation index during the study period (Henson et al., 2009; Hurrell \& Deser, 2009), but with increased wind stress in some locations, especially along the western North Atlantic. After removing these trends, models containing all the environmental factors considered at the same time but including only total wind stress or one of its components to avoid collinearity problems - explained an amount of variation in bloom timing and magnitude of $0.24[0.08,0.62]$ (fraction of deviance explained, median and $90 \%$ interval, Fig. S19). The importance of different variables varied depending on latitude and on the type of bloom (Fig. S20). The variable contributing to explain more deviance in bloom metrics presented a patchy distribution, although changes in wind forcing played a critical role in determining bloom characteristics in most of the basin (Fig. 5).

Sea surface temperature (SST) during the cold season was positively associated with delayed and more intense blooms in the polar North Atlantic and in the Irminger Sea (Fig. S20a). This result contrasted with the prevailing negative association found in the rest of the North Atlantic, either when considering spring or autumn/winter blooms. Zonal wind stress $\left(\tau_{\mathrm{u}}\right)$ and, to a lesser extent incident PAR, appeared as the most important factors in the rest of the northern North Atlantic (Fig. 5). Seasons with stronger westerlies corresponded to delayed and more intense spring blooms, while seasons with PAR above the average presented delayed and, to less extent, enhanced spring blooms (Fig. S20e and b respectively). The positive association between a delay in the timing of the bloom and its magnitude might seem counterintuitive, although it is partially a consequence of the way we defined the timing of the bloom. If we assume that chl $a$ dynamics obey a logistic function, an increase in the carrying capacity of 
(a)



(c)

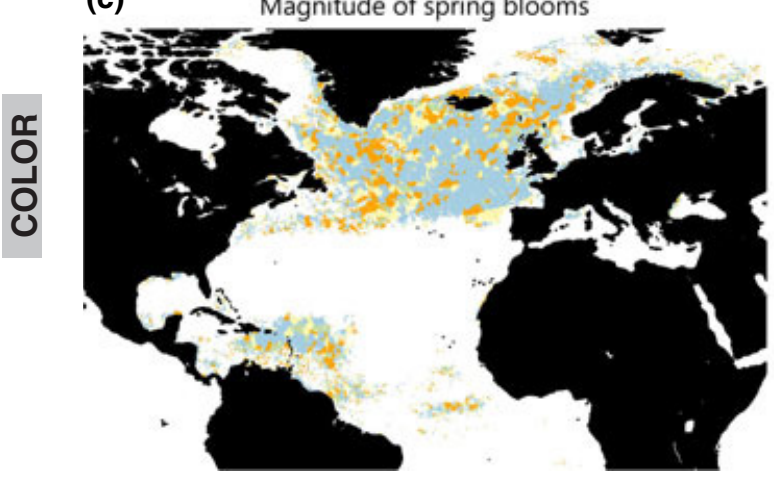

(b)

Timing of autumn/winter blooms

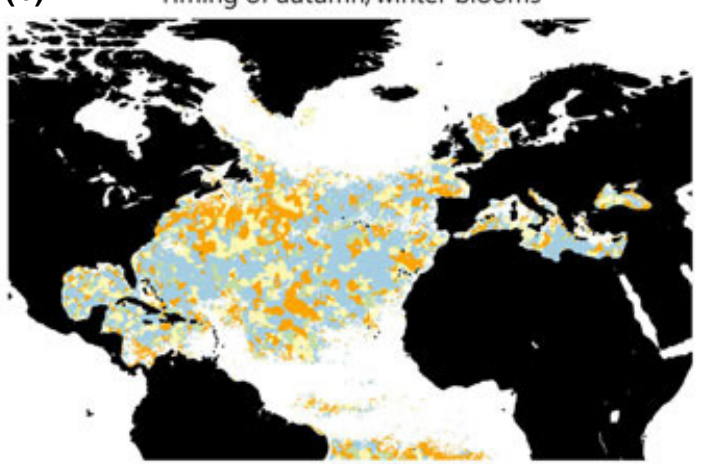

(d)

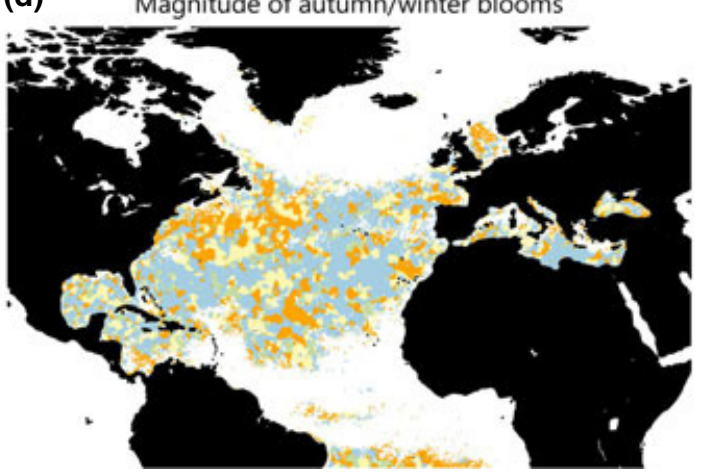

Sea surface temperature

Photosynthetic active radiation

Wind stress $\left(\mathrm{t}, \mathrm{\tau}_{\mathrm{u}}\right.$ and $\left.\mathrm{z}_{\mathrm{v}}\right)$

Eddy kinetic energy

Fig. 5 Environmental variables explaining most deviance in interannual changes in the timing (upper maps) and magnitude (lower maps) of spring and autumn/winter blooms in the North Atlantic during 1998-2012. A model including all the covariates considered in the study (Table 1) was fitted to bloom statistics, although combinations resulting in problems of collinearity were excluded (e.g., those including wind stress and its components). The covariate explaining more deviance was determined by comparing the decline in deviance explained after deleting each covariate one at a time. The amount of deviance explained is presented in the Supplementary Information.

the environment might cause a delay in the peak rate of 3 increase (Reynolds, 1997; proposed this reasoning to explain delays in the timing of the spring bloom associated with eutrophication). Positive anomalies in the meridional wind stress component $\left(\tau_{v}\right)$ were associated with delayed and stronger spring blooms along the European shelf (Fig. S20f). Changes in both spring and autumn/winter blooms in the transition zone were mainly associated with changes in SST and PAR, with a less important association with easterly winds and an important contribution of eddy kinetic energy along the Azores front (Fig. S20a-c). In contrast, wind stress $(\tau)$ was the main factor related to changes in the timing and intensity of autumn/winter blooms in the region presenting seasonal cycles with a single peak, especially in the Subtropical gyre (Fig. 5).

\section{Discussion}

We developed a novel approach to study changes in the seasonality of remotely sensed phytoplankton based on a probabilistic characterization of bloom incidence. This allowed us to detect changes in the prevalence of different seasonal cycles and to propagate uncertainty in bloom detection to estimates derived from bloom statistics. We found a greater incidence of seasonal cycles typical of subtropical latitudes in the temperate North Atlantic, as well as changes in the timing and magnitude of blooms in the whole basin. Interannual variability in phytoplankton seasonality responded to environmental factors, especially to changes in wind patterns in lower and mid-latitudes, and sea surface temperature and incident photosynthetically active radiation in the northern North Atlantic.

\section{Limitations and advantages of the methods employed to characterize seasonal changes in chl a concentration}

A variety of approaches have been proposed to characterize phytoplankton seasonality using remote sensing data (Ueyama \& Monger, 2005; Rolinski et al., 2007; Platt \& Sathyendranath, 2008; Thomalla et al., 2011; Zhai et al., 2011; Racault et al., 2012; Sapiano et al., 
2012). Daily observations are usually aggregated and smoothed spatially and/or in time before analysis in an attempt to surpass the limitations imposed by data scarcity during cloudy periods (Gregg \& Casey, 2007), which might otherwise result in huge biases in bloom statistics (Cole et al., 2012 report typical errors of 30 and 15 days for the timing of onset and peak date in subpolar regions). Here we have preserved the daily time scale of chl $a$ time series to minimize errors in bloom timing statistics, and instead tried to avoid problems derived from data gaps by increasing spatial coverage and, especially, by fitting a model to smooth available observations. We have not conducted a proper assessment of the effect of data gaps (e.g., Gregg \& Casey, 2007; Cole et al., 2012), but the relatively good agreement between estimates based on SeaWiFS and MODIS data indicates that this effect might remain low (the same cannot be ensured with respect to different chl $a$ algorithms), especially considering the larger number of valid chl $a$ retrievals provided by MODIS sensor each season. The detection of trends with different signs at the same latitudes also point in this direction (e.g., systematic biases usually consist in later bloom detections at high latitudes, see Cole et al., 2012).

Analyses of phytoplankton phenology usually proceed by determining the occurrence or not of a bloom to later retrieve the date of onset, bloom magnitude and other statistics like bloom duration or mean chl $a$ (e.g., Racault et al., 2012). Frequently, the timing of the bloom is determined as the date when either modelled or observed chl $a$ concentration reach the annual maximum or a threshold level which, in many cases, is determined based on a small fraction above median chl a concentration (e.g., 0.05). Both approaches assume that a bloom has occurred and thus, that chl $a$ data contain enough information to characterize it. Here, we fitted a model with enough flexibility to characterize different types of seasonal cycles of chl $a$ concentration (see Vargas et al., 2008; Sapiano et al., 2012). Seasonal chl $a$ data were previously subset based on sea surface temperature time series. This allowed us to accommodate interannual changes in the shape of the seasonal cycle (Jönsson \& Eklundh, 2002), and to determine directly the nature of blooms (i.e. spring vs. autumn/ winter). An alternative approach consists in requiring chl $a$ series to be above the threshold during two consecutive observations, a criterion which might be combined with setting a minimum variation in chl $a$ to consider that a bloom might have occurred in a given location (e.g., Cole et al.,2012).

The main difference with previous approaches consisted in avoiding the assumption that a bloom must have occurred and that it should be detected every year, i.e. ignoring changes in data availability or in the type of seasonal cycle. Our approach was similar in this aspect to Sapiano et al. (2012), although it does not require a nearly constant seasonal cycle year after year at the same location to determine the lack or not of a seasonal cycle (see Vantrepotte \& Mélin, 2009 for an alternative approach to the analyses of changes in chl a). Instead, we explored each oscillation in posterior simulations of models fitting available seasonal data. Observations retrieved during the target season - either spring or autumn/winter - were employed to estimate a threshold chl $a$ concentration. The number of posterior simulations exceeding this selected chl $a$ level was then used as an estimator of the probability of a bloom occurring or not. It should be noted that this procedure allowed us to detect changes in the prevalence of different seasonal cycles, to characterize uncertainty in bloom detection and, at the same time, to propagate this uncertainty to estimates derived from bloom statistics.

\section{Changes in phytoplankton seasonality}

We analysed changes in phytoplankton seasonality considering changes in the prevalence of different types of seasonal cycle, before examining changes in bloom timing and magnitude. In both cases, the length of the series poses a great limitation to ascribe observed trends to climate change (Henson et al., 2010), although it revealed a clear signature of climate forcing on interannual changes in bloom statistics. Other problems include the difficulties to interpret changes in remotely sensed chl $a$ concentration (see Materials and Methods), the indirect treatment of mixed layer dynamics and the lack of some important drivers of phytoplankton and bloom dynamics, like advection and sub-mesoscale features (Lehahn et al., 2007; Mahadevan et al., 2012). Another interesting aspect revealed by this study was the importance of taking into account potential differences between satellite missions and between chl $a$ algorithms (see the Supporting Text in the Supporting Information).

In agreement with previous studies highlighting an increased prevalence of oligotrophic conditions (McClain et al., 2004b; Polovina et al., 2008; Irwin \& Oliver, 2009), we found an increased prevalence of mean seasonal cycles with two peaks or even with a single autumn/winter bloom in the transition zone between regions presenting seasonal cycles with a single bloom, characteristic of subpolar and subtropical conditions. In the temperate North Atlantic, trends towards less apparent spring blooms contrasted with trends towards autumn/winter blooms of increased magnitude. At the same time, diverging trends in the timing of different peaks suggested an increase in seasonal stratification, the main consequence of increased surface warming 
(Sarmiento et al., 1998). Changes in bloom timing and magnitude might have also impacted several fisheries around the Atlantic (Platt et al., 2003; Koeller et al., 2009).

In the temperate North Atlantic, the association between changes in bloom metrics and environmental variables suggests that trends in bloom timing and magnitude reflect reduced light availability during winter and especially, an increased stratification due to surface warming and reduced wind stress (Henson et al., 2009). Indeed, opposite trends in mean chl $a$ on both sides of the basin in middle latitudes might be explained by different trends in wind stress. Weaker westerlies during winter might result in a decrease in mixed layer ventilation and nutrient renewal in the Northeast Atlantic, resulting in spring blooms of a reduced magnitude and a decrease in annual mean chl $a$ concentration. These changes in seasonal wind patterns might be related to the widening of tropical wind circulation systems (Seidel et al., 2007), and thus its effects on phytoplankton seasonality might continue and even strengthen in the next few decades.

Delayed and more intense blooms were found in most of the Subpolar gyre, although advanced and less intense blooms were more common in polar latitudes (Kahru et al., 2011; Racault et al., 2012). These changes were mainly associated with surface warming and light availability. In the Subtropical gyre, the different response on both sides of the North Atlantic can be explained again by changes in wind stress, although in this case the mechanism involved might be related to an increase in pigment cell levels in response to deeper mixing (Siegel et al., 2005). Advanced and less intense blooms in the eastern side contrasted with delayed blooms of increased magnitude in the western subtropics, coinciding with trends of the same sign in mean chl a. All these changes in the seasonality of North Atlantic phytoplankton highlight the tight link between climate forcing and the dynamics of ocean ecosystems, stressing the value of remote sensing data for the monitoring, assessment, and projection of future climate change impacts on ocean ecosystems.

\section{Acknowledgements}

We thank NASA Ocean Biology Processing Group and Physical Oceanography Distributed Active Archive Center (PO.DAAC), NOAA National Climatic Data Center (NCDC) and the Centre Nationel d'Etudes Spatiales (CNES) for the availability, production and maintenance of the remote sensing data employed in this manuscript. The altimeter products were produced by Ssalto/Duacs and distributed by Aviso with support from CNES. JA Sostres provided support and helped us with data management and analyses. I Martínez, C Cáceres, J Höfer, A. Molina and JL Acuna provided valuable comments and discussion on earlier versions of the manuscript. Five anonymous reviewers and the editor provided careful reviews that are greatly acknowledged and improved greatly the quality of the manuscript. FGT acknowledges a FICYT "Severo Ochoa" grant (PCTI 2006-2009, Gobierno del Principado de Asturias). Our work has been supported by project DOS MARES (CTM2010-21810- C0302, Ministerio de Economía y Competitividad, Gobierno de España).

\section{References}

Antoine D, Morel A, Gordon HR, Banzon VF, Evans RH (2005) Bridging ocean color observations of the 1980s and 2000s in search of long term trends. Journal of Geophysical Research, 110, C06009.

Atlas R, Hoffman RN, Ardizzone J, Leidner SM, Jusem JC, Smith DK, Gombos D (2011) A cross-calibrated, multiplatform ocean surface wind velocity product for meteorological and oceanographic applications. Bulleting of the American Meteorological Society, 92, 157-174.

Barnes RSK, Hughes R (1999) An Introduction to Marine Ecology, 3rd edn. Blackwell Publishing, Oxford, UK

Beaugrand G, Brander KM, Lindlay JA, Souissi A, Reid PC (2003) Plankton effect on cod recruitment in the North Sea. Nature, 426, 661-664.

Behrenfeld MJ (2010) Abandoning Sverdrup's critical depth hypothesis on phytoplankton blooms. Ecology, 91, 977-989.

Behrenfeld MJ, Boss E, Siegel DA, Shea DM (2005). Carbon-based ocean productivity and phytoplankton physiology from space. Global Biogeochemical Cycles, 19 GB1006.

Behrenfeld MJ, O'Malley RT, Siegel DA et al. (2006) Climate-driven trends in ocean contemporary ocean productivity. Nature, 444, 752-754.

Billett DSM, Lampitt RS, Rice AL, Mantoura RFC (1983) Seasonal sedimentation of phytoplankton to the deep-sea benthos. Nature, 302, 520-522

Bosc E, Bricaud A, Antoine D (2004). Seasonal and interannual variability in algal biomass and primary production in the Mediterranean Sea, as derived from 4 years of SeaWiFS observations. Global Biogeochemical Cycles, 18: GB1005.

Burnham KP, Anderson S (2003) Model Selection and Multi-Model Inference: A Practical Information-Theoretic Approach, 2nd edn. Springer, New York, USA.

Campbell G, Mosimann JE (1987). Multivariate methods for proportional shape modelling with the Dirichlet distribution. In: Computer Science and Statistics: proceeding of the 19th Symposium on the Interface (eds Heiberger RM), pp 93-101. American Statistical Association, ???

Cole H, Henson S, Martin A, Yool A (2012) Mind the gap: the impact of missing data on the calculation of phytoplankton phenology metrics. Journal of Geophysical Research, 117, C08030

Coles VJ, Wilson C, Hood RR (2004) Remote sensing of new production fuelled by nitrogen fixation. Geophysical Research Letters, 31, L06301.

Cushing DH (1990) Plankton production and year-class strength in fish populations: an update of the match/mismatch hypothesis. Advances in Marine Biology, 26, 249-293.

Deuser WG, Ross EH (1980) Seasonal change in the flux of organic carbon to the deep Sargasso Sea. Nature, 283, 364-365.

DuRand MD, Olson RJ, Chrisholm SW (2001) Phytoplankton population dynamics at the Bermuda Atlantic time-series station in the Sargasso Sea. Deep Sea Research II: Topical Studies in Oceanography, 48, 1983-2003.

Durant JM, Hjermann DØ, Ottersen G, Stenseth NC (2007) Climate and the match or mismatch between predator requirements and resource availability. Climate Research, 33, 271-283.

Dutkiewicz S, Follows M, Marshall J, Gregg WW (2001) Interannual variability of phytoplankton abundances in the North Atlantic. Deep-Sea Research Part II Topical Studies in Oceanography, 48, 2323-2344.

Edwards M, Richardson AJ (2004) Impact of climate change on marine pelagic phenology and trophic mismatch. Nature, 430, 881-884.

Edwards M, Reid P, Planque B (2001) Long-term and regional variability of phytoplankton biomass in the Northeast Atlantic (1960-1995). ICES Journal of Marine Science, 58, 39-49.

Falkowski PG, Barber RT, Smetacek V (1998) Biogeochemical controls and feedbacks on ocean primary production. Science, 281, 200-206.

Feldman GC, McClain CR(2012). Ocean Color Web, SeaWiFS and Aqua MODIS Reprocessing 2010.0, (eds Kuring N, Bailey SW).NASA Goddard Space Flight Center. Accessed 1 October 2012. oceancolor.gsfc.nasa.gov. 
Garver SA, Siegel DA (1997) Inherent optical property inversion of ocean color spectra and its biogeochemical interpretation: I. time series from the Sargasso Sea. Journal of Geophysical Research, 102, 18607-18625.

Gelman A, Hill J (2007) Data Analysis Using Regression and Multilevel/Hierarchical Models. Cambridge University Press, New York, USA.

Gelman A, Jakulin A, Pitatu MG, Su YS (2008) A weakly informative default prior distribution for logistic and other regression models. The Annals of Applied Statistics, 2, 1360-1383.

Gelman A, Su YS, Yajima M, Hill J, Pittau MG, Kerman J, Zheng T (2009). Arm: Data analysis using regression and multilevel/hierarchical models. $\mathrm{R}$ package version $1.2-9,2009$.

Gregg WW, Casey NW (2007) Sampling biases in MODIS and SeaWiFS ocean chlorophyll data. Remote Sensing of the Environment, 111, 25-35.

Gregg WW, Conkright ME (2002) Decadal changes in global ocean chlorophyll. Geophysical Research Letters, 29 (1730), 2002.

Gregg WW, Casey NW, McClain CR (2005) Recent trends in global ocean chlorophyll. Geophysical Research Letters, 32, L03606.

Henson SA, Dunne JP, Sarmiento JL (2009) Decadal variability in North Atlantic blooms. Journal of Geophysical Research, 114, C04013.

Henson SA, Sarmiento JL, Dunne JP et al. (2010) Detection of anthropogenic climate change in satellite records of ocean chlorophyll and productivity. Biogeosciences, 7, 621-641.

Hijazi RH, Jernigan RW (2009) Modelling compositional data using Dirichlet regression models. Journal of Applied Probability and Statistics, 4, 10-17.

Hjort J(1914) Fluctuations in the great fisheries of northern Europe viewed in the light of biological research. Rapports et Procs-Verbaux des Reunions, Conseil International, pour I'Exploration de la Mer, 20: 1-228.

Honjo S (1982) Seasonality and interaction of biogenic and lithogenic particulate flux at the Panama basin. Science, 218, 883-884.

Hu C, Lee Z, Franz B (2012) Chlorophyll $a$ algorithms for oligotrophic oceans: a novel approach based on three-band reflectance difference. Journal of Geophysical Research, 117, C01011.

Hurrell JW, Deser C (2009) North Atlantic climate variability: the role of the North Atlantic Oscillation. Journal of Marine Systems, 78, $28-41$.

Irigoien X, Flynn KJ, Harris RP (2005) Phytoplankton blooms: a 'loophole' in microzooplankton grazing impact? Journal of Plankton Research, 27, 313-321.

Irwin AJ, Oliver MJ (2009) Are ocean deserts getting larger? Geophysical Research Letters, 36, L18609.

Jönsson P, Eklundh L (2002) Seasonality extraction by function fitting to time-series of satellite sensor data. IEEE Transactions on Geoscience and Remote Sensing, 10, 1824 1832.

Kahru M, Brotas V, Manzano-Sarabia M, Mitchell BG (2011) Are phytoplankton blooms occurring earlier in the arctic? Global Change Biology, 17, 1733-1739.

Karrasch B, Hoppe HG, Ullrich S, Podewski S (1996) The role of mesoscale hydrography on microbial dynamics in the northeast Atlantic: results of a spring bloom experiment. Journal of Marine Research, 54, 99-122.

Koeller P, Fuentes-Yaco C, Platt T et al. (2009) Basin-scale coherence in phenology of shrimps and phytoplankton in the North Atlantic Ocean. Science, 324, 791-793.

Kristiansen T, Drinkwater KF, Lough RG, Sundby S(2011). Recruitment variability in North Atlantic cod and match-mismatch hypothesis. PLoS ONE, 6: e17456.

Laws EA, Bannister TT (1980) Nutrient- and light-limited growth of Thalassiosira fluviatilis in continuous culture, with implications for phytoplankton growth in the ocean. Limnology and Oceanography, 25, 457-473.

Le Traon PY, Nadal F, Ducet N (1998) An improved mapping method of multisatellite altimeter data. Journal of Atmospheric and Oceanic Technology, 15, 522-534

Lehahn Y, d'Ovidio F, Lévy M, Heifetz E (2007) Stirring of the northeast Atlantic spring bloom: a lagrangian analysis based on multisatellite data. Journal of Geophysical Research, 112, C08005.

Letelier R, Bidigare LL, Hebel DV, Ondrusek M, Winn CD, Karl DM (1993) Temporal variability of phytoplankton community structure based on pigment analysis. Limnology and Oceanography, 38, 1420-1437.

Longhurst AR (2007) Ecological Geography of the Sea, 2nd edn. Academic Press, London, UK.

Mahadevan A, D'Asaro E, Lee C, Perry MJ (2012) Eddy-driven stratification initiates North Atlantic spring phytoplankton blooms. Science, 337, 54-58.

Maritorena S, Siegel DA, Peterson AR (2002) Optimization of a semianalytical ocean color model for global-scale applications. Applied Optics, 41, 2705-2714.

Maritorena S, d'Andon OHF, Magin A, Siegel DA (2010) Merged satellite ocean color data products using a bio-optical model: characteristics, benefits and issues. Remote Sensing of the Environment, 114, 1791-1804.
Martinez E, Antoine D, D'Ortenzio F, Gentili B (2009) Climate-driven basin-scale decadal oscillations of oceanic phytoplankton. Science, 326, 1243-1256.

Martinez E, Antoine D, D'Ortenzio F, de Boyer Montegut C (2011) Phytoplankton spring and fall blooms in the North Atlantic in the 1980s and 2000s. Journal of Geophysical Research, 116, C11029.

McClain CR (2009) A decade of satellite ocean color observations. Annual Review of Marine Science, 1, 19-42.

McClain CR, Feldman GC, Hooker SB (2004a) An overview of the SeaWiFS project and strategies for producing a climate research quality global ocean bio-optical time series. Deep-Sea Research Part II Topical Studies in Oceanography, 51, 5-42.

McClain CR, Signorini SR, Christian JR (2004b) Subtropical gyre variability observed by ocean-color satellites. Deep-Sea Research Part II Topical Studies in Oceanography, 51, 281-301.

Meister G, Franz BA, Kwiatkowska EJ, McClain CR (2012) Corrections of the calibration of MODIS Aqua ocean color bands derived from SeaWiFS data. IEEE Transactions on Geoscience and Remote Sensing, 50, 310-319.

O'Reilly JE, Maritorena S, Siegel DA et al. (2000) Ocean color chlorophyll a algorithms for SeaWiFS, OC2, and OC4: Version 4. In: SeaWiFS Postlaunch Calibration and Validation Analyses, Part 3(eds O'Reilly JE, Maritorena S, O'Brien MC et al.), pp. 8-22. NASA Tech. Memo. 2000-206892, Vol. 11, (eds Hooker SB, Firestone ER), NASA Goddard Space Flight Center. ????

Parmesan C (2007) Influences of species, latitudes and methodologies on estimates of phenological response to global warming. Global Change Biology, 13, 1860-1872.

Peñuelas J, Filella I (2001) Responses to a warming world. Science, 294, 793-795.

Platt T, Sathyendranath S (2008) Ecological indicators for the pelagic zone of the ocean from remote sensing. Remote Sensing of Environment, 112, 3426-3436.

Platt T, Bird DF, Sathyendranath S (1991) Critical depth and marine primary productivity. Proceedings of the Royal Society London B, 246, 205-217.

Platt T, Fuentes-Yaco C, Frank KT (2003) Spring algal bloom and larval fish survival. Nature, 423, 398-399.

Polovina JJ, Woodworth PA (2012) Declines in phytoplankton cell size in the subtropical oceans estimated from satellite remotely-sensed temperature and chlorophyll 1998-2007. Deep-Sea Research Part II Topical Studies in Oceanography, 77-80, 82-88.

Polovina JJ, Howell EA, Abecassis M (2008) Ocean's least productive waters are expanding. Geophysical Research Letters, 35, L03618.

Racault MF, Le Quéré C, Buitenhuis E, Sathyendranath S, Platt T (2012) Phytoplankton phenology in the global ocean. Ecological Indicators, 14, 152-163.

Reid PC, Edwards M, Hunt HG, Warner AJ (1998) Phytoplankton change in the North Atlantic. Nature, 391, 546

Reynolds CS (1997) Successional development, energetics and diversity in planktonic communities. In: Biodiversity: An Ecological Perspective (eds Abe T, Levin SA, Higashi M), pp. 167-202. Springer, New York, NY, USA.

Reynolds RW, Smith TM, Liu C, Chelton DB, Casey KS, Schlax MG (2007) Daily highresolution-blended analyses for sea surface temperature. Journal of Climate, 20, 5473-5496.

Roberts GO, Rosenthal JS (2009) Examples of adaptive MCMC. Journal of Computational and Graphical Statistics, 18, 349-367.

Rolinski S, Horn H, Petzoldt T, Paul L (2007) Identifying cardinal dates in phytoplankton time series to enable the analysis of long-term trends. Oecologia, 153, 9971008.

Sapiano MRP, Brown CW, Schollaert Uz S, Vargas M (2012) Establishing a global climatology of marine phytoplankton phenological characteristics. Journal of Geophysical Research, 117, C08026.

Sarmiento JL, Hughes TMC, Stouffer RJ, Manabe S (1998) Simulated response of the ocean carbon cycle to anthropogenic climate warming. Nature, 393, 245-249.

Seidel DJ, Fu Q, Randel WJ, Reichler TJ (2007) Widening of the tropical belt in a changing climate. Nature Geoscience, 1, 21-24.

Siegel DA, Doney SC, Yoder JA (2002) The North Atlantic spring phytoplankton bloom and Sverdrup's critical depth hypothesis. Science, 296, 730-733.

Siegel DA, Maritorena S, Nelson NB, Behrenfled MJ (2005) Independence and interdependencies among global ocean color properties: reassessing the bio-optical assumption. Journal of Geophysical Research, 110, C07011.

Sletzer H, Post E (2009) Seasons and life cycles. Science, 324, 886-887.

Subramaniam A, Yager PL, Carpenter EJ et al. (2008) Amazon river enhances diazotrophy and carbon sequestration in the tropical North Atlantic Ocean. Proceedings of the National Academy of Sciences USA, 105, 10460-10465.

Sverdrup HU (1953) On conditions for the vernal blooming of phytoplankton. Journal $d u$ conseil/Conseil international pour l'exploration de la mer, 18, 287-295.

Thomalla SJ, Fauchereau N, Swart S, Monteiro PMS (2011) Regional scale characteristics of the seasonal cycle of chlorophyll in the Southern Ocean. Biogeosciences, 8 2849-2866. 
Townsend DW, Cammen LM, Holligan PM, Campbell DE, Pettigrew NR (1994) Causes and consequences of variability in the timing of spring phytoplankton blooms. Deep-Sea Research Part I Oceanographic Research Papers, 41: 747-765.

Ueyama R, Monger BC (2005) Wind-induced modulation of seasonal phytoplankton blooms in the North Atlantic derived from satellite observations. Limnology and Oceanography, 50, 1820-1829.

Vantrepotte V, Mélin F (2009) Temporal variability of 10-year global SeaWiFS timeseries of phytoplankton chlorophyll a concentration. ICES Journal of Marine Science, 66, 1547-1556.

Vantrepotte V, Loisel H, Mélin F, Desailly D, Duforêt-Gaurier L (2011) Global particulate matter pool temporal variability over the SeaWiFS period (1997-2007). Geophysical Research Letters, 38, L02605.

Vargas M, Brown CW, Sapiano MRP (2008) Phenology of marine phytoplankton from satellite ocean color measurements. Geophysical Research Letters, 36, L01608.

Westberry T, Behrenfeld MJ, Siegel DA, Boss E (2008). Carbon-based primary productivity modeling with vertically resolved photoacclimation. Global Biogeochemical Cycles, 22: GB2024.

Yelland MJ, Taylor PK (1996) Wind stress measurements from the open ocean. Journal of Physical Oceanography, 26, 541-558.
Yelland MJ, Moat BI, Taylor PK, Pascal RW, Hutchings J, Cornell VC (1998) Wind stress measurements from the open ocean corrected for airflow distortion by the ship. Journal of Physical Oceanography, 28, 1511-1526.

Zhai L, Platt T, Tang C, Sathyendranath S, Hernández Walls R (2011) Phytoplankton phenology on the Scotian Shelf. ICES Journal of Marine Science, 68, 781-791.

\section{Supporting Information}

Additional Supporting Information may be found in the online version of this article:

Data S1. Detection and characterization of blooms: SeaWiFS vs. Aqua MODIS.

Data S2. Effect of chl a algorithm on incidences and derived estimates.

Data S3. Retrieval of chl a data and estimation of bloom metrics (extra discussion). 


\section{Author Query Form}

\section{Journal: $\quad$ GCB}

Article: $\quad 12352$

Dear Author,

During the copy-editing of your paper, the following queries arose. Please respond to these by marking up your proofs with the necessary changes/additions. Please write your answers on the query sheet if there is insufficient space on the page proofs. Please write clearly and follow the conventions shown on the attached corrections sheet. If returning the proof by fax do not write too close to the paper's edge. Please remember that illegible mark-ups may delay publication.

Many thanks for your assistance.

\begin{tabular}{|l|l|l|}
\hline Query reference & Query & Remarks \\
\hline 1 & $\begin{array}{l}\text { AUTHOR: Vargas et al. 2009 has been } \\
\text { changed to Vargas et al., 2008 so that } \\
\text { this citation matches the Reference List. } \\
\text { Please confirm that this is correct. }\end{array}$ & \\
\hline 2 & $\begin{array}{l}\text { AUTHOR: Hizaji and Jernigan 2009 has } \\
\text { been changed to Hijazi and Jernigan, } \\
\text { 2009 so that this citation matches the }\end{array}$ & $\begin{array}{l}\text { Reference List. Please confirm that this is } \\
\text { correct. }\end{array}$ \\
\hline 3 & $\begin{array}{l}\text { AUTHOR: Reynolds et al. 1997 has } \\
\text { been changed to Reynolds, 1997 so that } \\
\text { this citation matches the Reference List. } \\
\text { Please confirm that this is correct. }\end{array}$ & \\
\hline 4 & $\begin{array}{l}\text { AUTHOR: Please provide the publisher } \\
\text { location for reference Campbell and } \\
\text { Mosimann (1987). }\end{array}$ & \\
\hline 5 & $\begin{array}{l}\text { AUTHOR: Hu et al. (2012) has not been } \\
\text { cited in the text. Please indicate where it } \\
\text { should be cited; or delete from the } \\
\text { Reference List. }\end{array}$ & \\
\hline 6 & $\begin{array}{l}\text { AUTHOR: Please provide the publisher } \\
\text { location for reference O'Reilly et al. } \\
\text { (2000). }\end{array}$ & \\
\hline
\end{tabular}


Required software to e-Annotate PDFs: Adobe Acrobat Professional or Adobe Reader (version 8.0 or above). (Note that this document uses screenshots from Adobe Reader $\mathrm{X}$ )

The latest version of Acrobat Reader can be downloaded for free at:http://get.adobe.com/reader/

Once you have Acrobat Reader open on your computer, click on the Comment tab at the right of the toolbar:

닙

This will open up a panel down the right side of the document. The majority of tools you will use for annotating your proof will be in the Annotations section, pictured opposite. We've picked out some of these tools below:

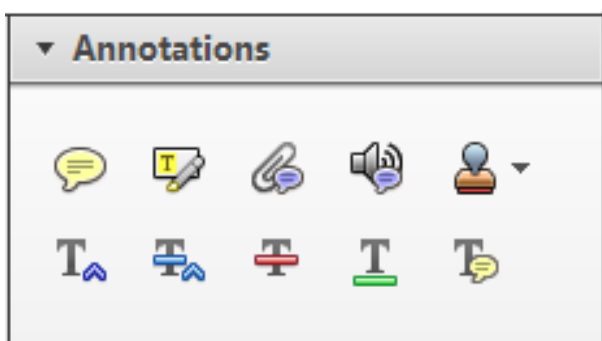

1. Replace (Ins) Tool - for replacing text.

\section{Strikes a line through text and opens up a text} box where replacement text can be entered.

\section{How to use it}

- Highlight a word or sentence.

- Click on the Replace (Ins) icon in the Annotations section.

- Type the replacement text into the blue box that appears.

Idard tramework for the analysis of $\mathrm{m}$ icy Nevertheless, it also led to exog،


aber of comp 08/06/2011 15:58:17 $\quad$ o


nain compo: be level, are exc nc

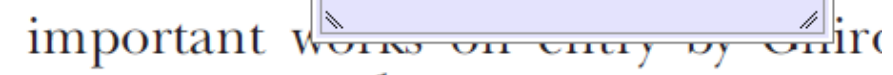
M heneforth) ${ }^{1}$ we anen the 'hlarl $\mathrm{h}$

3. Add note to text Tool - for highlighting a section to be changed to bold or italic.

Th Highlights text in yellow and opens up a text box where comments can be entered.

\section{How to use it}

- Highlight the relevant section of text.

- Click on the Add note to text icon in the Annotations section.

- Type instruction on what should be changed regarding the text into the yellow box that annears.

namic responses of mark ups ent with the VAR evidence



2. Strikethrough (Del) Tool - for deleting text.

Thikes a red line through text that is to be deleted.

\section{How to use it}

- Highlight a word or sentence.

- Click on the Strikethrough (Del) icon in the Annotations section.

there is no room for extra protits al c ups are zero and the number of ret) values are not determined by Blanchard and Kiyetaki (1987), rfect competition in general equilil ts of aggregate demand and supply lassical framework assuming monol eon an evorenois number of firms

\section{Add sticky note Tool - for making notes at} specific points in the text.

\section{Marks a point in the proof where a comment} needs to be highlighted.

\section{How to use it}

- Click on the Add sticky note icon in the Annotations section.

- Click at the point in the proof where the comment should be inserted.

- Type the comment into the yellow box that appears.

lallu allu suppiy silucks. Iviusl ul

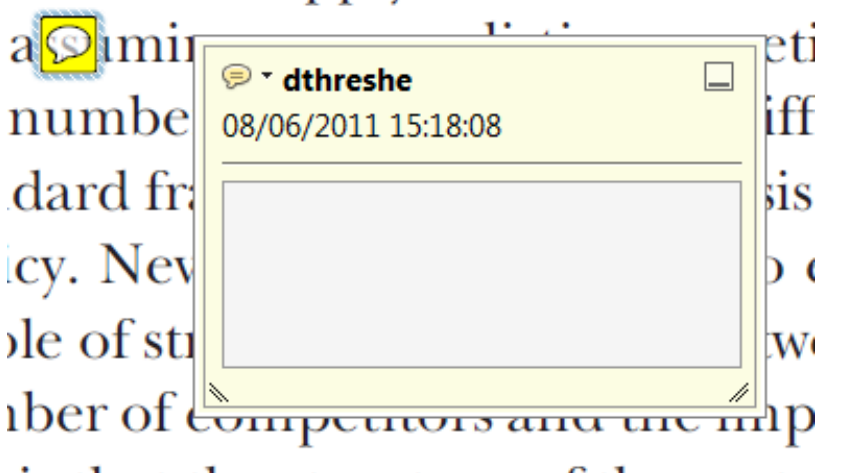

is that the structure of the secto 
5. Attach File Tool - for inserting large amounts of text or replacement figures.

Inserts an icon linking to the attached file in the appropriate pace in the text.

How to use it

- Click on the Attach File icon in the Annotations section.

- Click on the proof to where you'd like the attached file to be linked.

- Select the file to be attached from your computer or network.

- Select the colour and type of icon that will appear in the proof. Click OK.

E N D



6. Add stamp Tool - for approving a proof if no corrections are required.

- Inserts a selected stamp onto an appropriate place in the proof

\section{How to use it}

- $\quad$ Click on the Add stamp icon in the Annotations section.

- Select the stamp you want to use. (The Approved stamp is usually available directly in the menu that appears).

- Click on the proof where you'd like the stamp to appear. (Where a proof is to be approved as it is, this would normally be on the first page).

of the Dusiness cycie, starting with the on perfect competition, constant ret

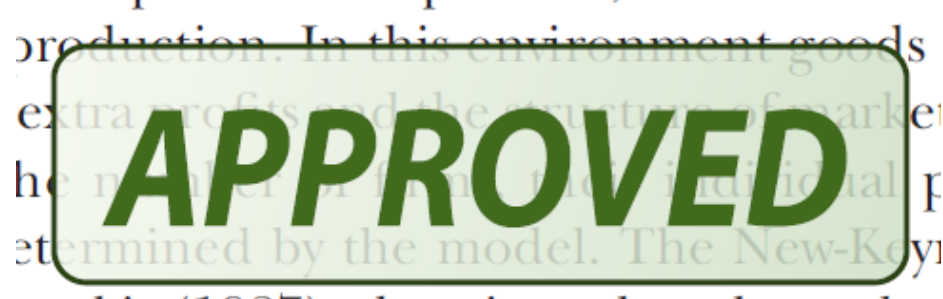

otaki (1987), has introduced produc general equilibrium models with nomin
- Drawing Markups

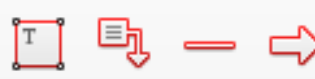

$0 \square \sqrt{6} D$

\section{How to use it}

- Click on one of the shapes in the Drawing Markups section.

- Click on the proof at the relevant point and draw the selected shape with the cursor.

- To add a comment to the drawn shape, move the cursor over the shape until an arrowhead appears.

- Double click on the shape and type any text in the red box that appears.
7. Drawing Markups Tools - for drawing shapes, lines and freeform annotations on proofs and commenting on these marks.

Allows shapes, lines and freeform annotations to be drawn on proofs and for comment to be made on these marks..



For further information on how to annotate proofs, click on the Help menu to reveal a list of further options:



